\title{
Halo Blight of Mungbean in Australia
}

\author{
Araz Sedqi Abdullah *,+ and Col Douglas
}

Department of Agriculture and Fisheries, Hermitage Research Facility, Warwick 4370, Australia; col.douglas@daf.qld.gov.au

* Correspondence: araz.solman@daf.qld.gov.au

+ Author also known as Araz Solman.

Citation: Abdullah, A.S.; Douglas, C. Halo Blight of Mungbean in Australia. Crops 2021, 1, 3-7. https://doi.org/ $10.3390 /$ crops 1010002

Academic Editor: Il-Ryong Choi Received: 9 April 2021

Accepted: 13 May 2021

Published: 17 May 2021

Publisher's Note: MDPI stays neutral with regard to jurisdictional claims in published maps and institutional affiliations.

\begin{abstract}
Halo blight, one of the major diseases of mungbean, is caused by the bacterium Pseudomonas savastanoi pv. phaseolicola. The pathogen infects the foliar parts of the plant, causing water-soaked spots that eventually develop surrounding yellow margins. The disease is particularly destructive under moderate temperature and high humidity, especially when it occurs during late vegetative through to early reproductive stage. In such conditions, severely infected crops could experience a yield loss up to $70 \%$. Halo blight can be widespread on mungbeans grown in Southern Queensland and Northern New South Wales. However, due to its seedborne and cryptic nature of transmission, the disease is likely to be under-reported. This report addresses major aspects of halo blight symptomology, pathology and epidemiology.
\end{abstract}

Keywords: Vigna radiata; P. phaseolicola; bacterial disease; disease management

\section{The Pathogen and Disease Symptoms}

Halo blight is a major mungbean disease caused by the foliar bacterium Pseudomonas savastanoi pv. phaseolicola. The disease was first reported in Queensland in the early 1980s and has since become a widespread constraint affecting the reliability and yield of mungbeans. The bacterium's seedborne nature and broad host range contribute to the widespread distribution of the halo blight disease. However, due to unfamiliarity with disease symptoms and the possibility of mixed infections, halo blight is likely to be under-reported. Recent genomic analysis suggests the existence of several pathotypes of the causal agent of halo blight [1]. This highlights the significance of conducting annual surveillance at a level sufficient to monitor and characterise pathogen virulences as they respond to changes in host genotype and growing conditions. Virulences identified can then be evaluated against current breeding lines and commercial varieties to inform and direct future breeding activities.

While halo blight can occur on seedlings early in the season, the main damage often occurs when the infection reaches the epidemic stage during and after flowering. Typical symptoms of the disease initially appear as small, dark, circular spots. These eventually develop necrotic lesions surrounded by yellow margins (Figures 1 and 2). Advanced lesions can join, giving rise to large necrotic areas scattered on both sides of the infected leaf (Figure 2B,C). Stress plants, including those exposed to waterlogging, high wind rainfall events or water stress, are more likely to show disease symptoms and suffer significant yield loss. Even stress associated with flowering may be sufficient to induce susceptibility for significant halo blight disease. The disease is wind- and rain-dispersed, spreading the infection to uninfected leaves and neighbouring plants throughout the crop.

Studies have shown that halo blight bacterium can rapidly reach high densities without causing visible disease symptoms [2]. This suggests that apparent lack of symptoms is not indicative of a pathogen-free crop. In fact, dispersal of bacteria is likely to precede symptom development, making physical movement of the pathogen within and between crops less detectable. Symptoms can subsequently express following physical injury from 
rain and hail; these are thought to trigger a widespread pathogenic shift [2]. Therefore, movement of equipment through and between paddocks should be carefully considered, as symptomless mungbeans can harbour the pathogen. Mechanical damage and physical movement may spread the disease across the paddocks [3]. Growers and agronomists should implement a 'come clean-go clean' approach, which has proven successful in many other crops such as cotton [4]. Vehicles and machineries should be properly cleaned before leaving one paddock so that they arrive clean at the next paddock.
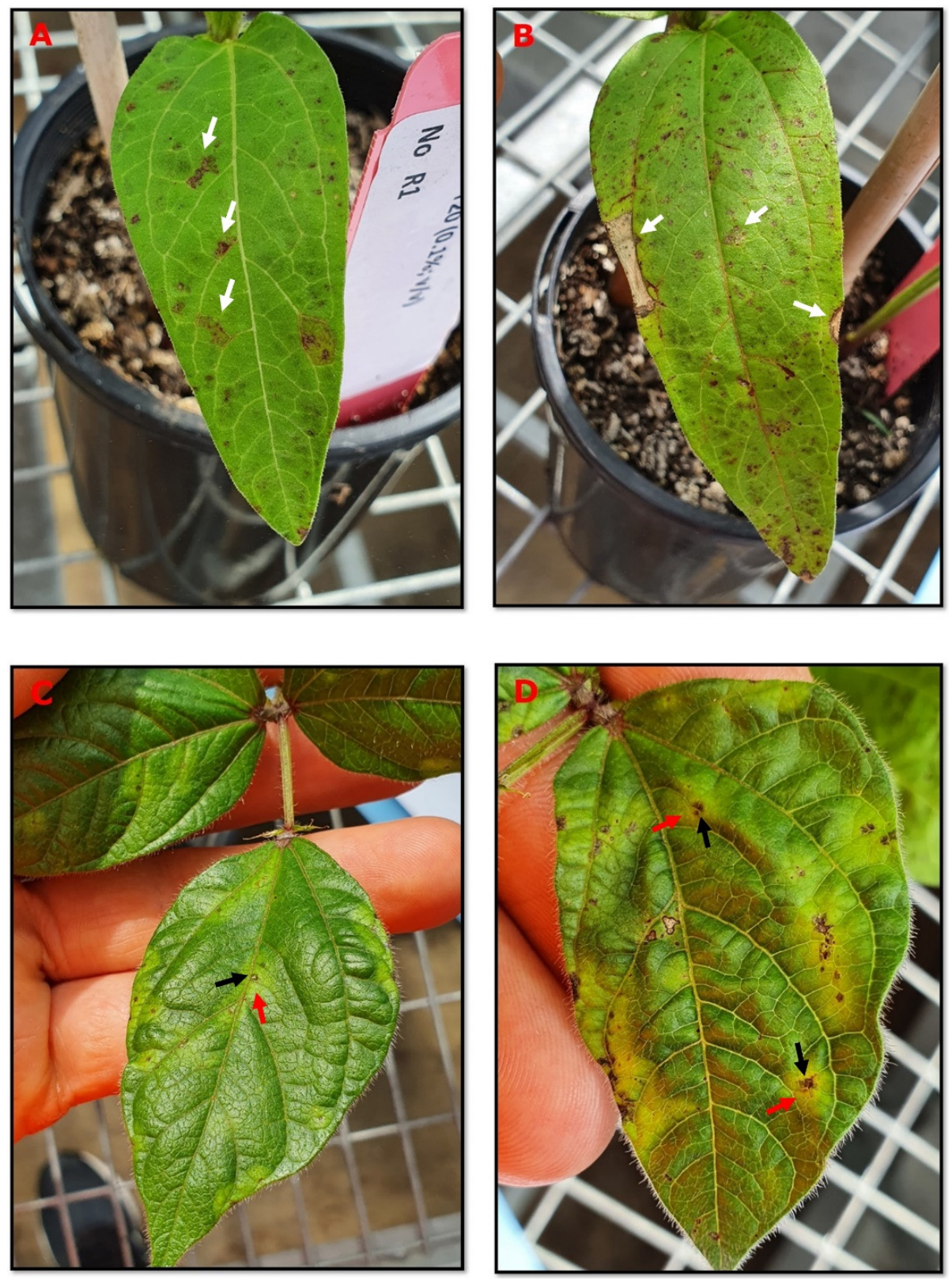

Figure 1. Examples of mungbean leaves, cultivar Berken, showing halo blight symptoms. On the cotyledons, symptoms initially appear as irregular shaped spots scattered throughout the tissue ((A) picture collected 6 days after inoculation). These can join, causing large, irregular-shaped chlorotic lesions ((B) picture collected 12 days after inoculation). On the trifoliate leaves, initial symptoms appear as regular-shaped, water-soaked circular spots surrounded by large chlorotic margins ((C) picture collected 6 days after inoculation). These develop large necrotic lesions by about 12 days after inoculation (D). White arrows in A and B indicate the presence of chlorotic tissues. Black and red arrows in $\mathrm{C}$ and $\mathrm{D}$ indicate the presence of necrotic and water-soaked lesions, respectively. 

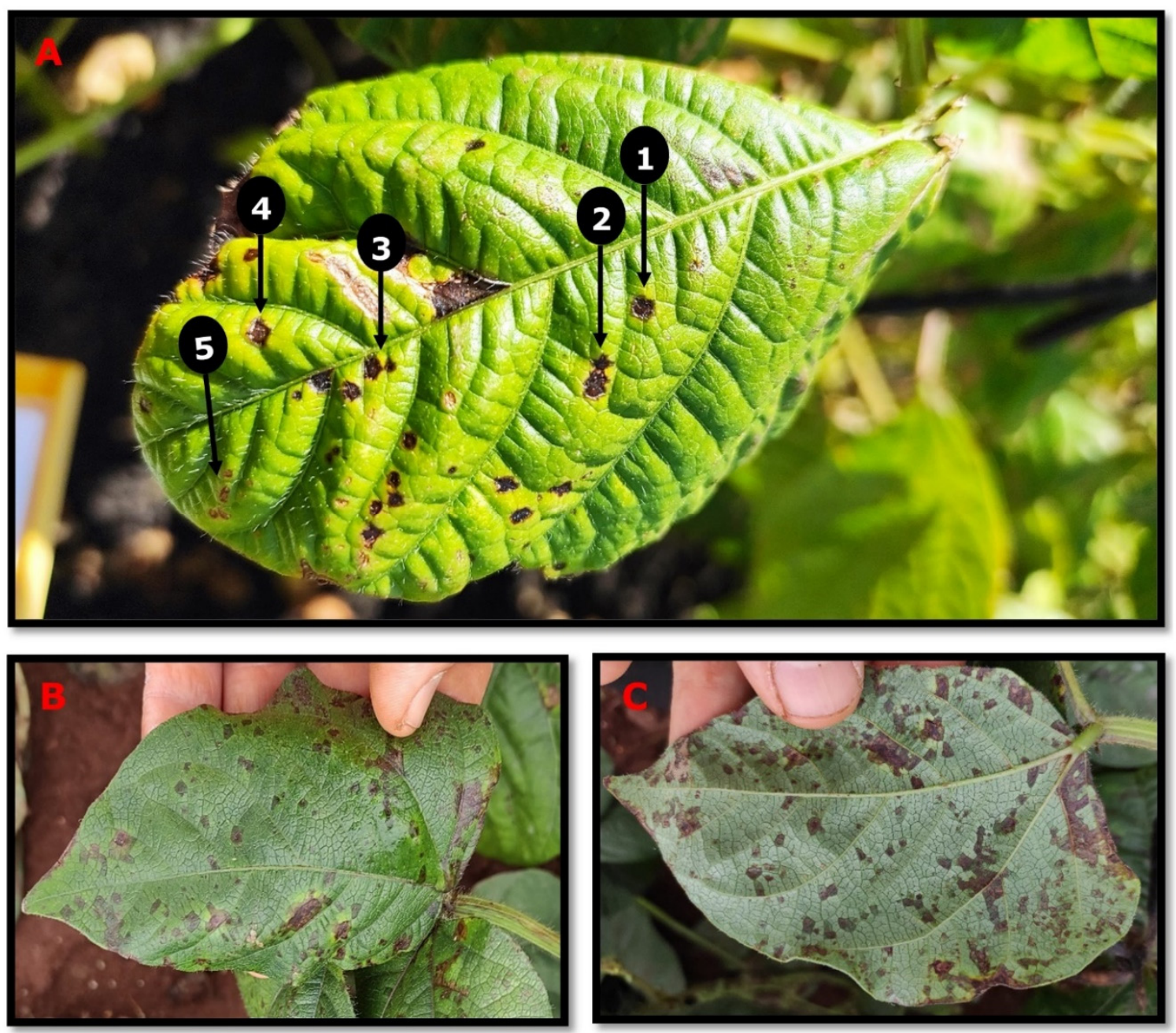

Figure 2. The '5Rs' diagnostic scheme showing symptom progression on a halo blight infected leaf (A). (1) Ringed with yellow margin, (2) rectangular shape lesions, (3) restricted by the leaf veins, (4) reddish-brown colouration, (5) rampant throughout the leaf. Halo blight symptoms on the upper (B) and lower (C) sides of the leaf.

\section{Pathogen Survival and Disease Spread}

The causal agent of halo blight survives the intercropping periods on alternative hosts, in infected seeds and plant debris from previous seasons. Infected seed represents the major mode of survival and transport of the pathogen [3]. The pathogen can invade the plant through stomatal openings but, more notably, through wounds and injuries created by heavy rainfall and wind. The disease can be spread by rain-splash, contact between wet leaves and irrigation water, as well as by people and animal movements through infested crops. Rain splash permits disease transmission, especially when there is a prevailing wind that facilitates movement of the pathogen over long distances (Figure 3). Halo blight flourishes in moderately low temperatures $\left(18-26^{\circ} \mathrm{C}\right)$ with periods of high relative humidity (i.e., during and following heavily rainfall). The disease causes yield loss by reducing leaf area available for photosynthesis [5]. Yield losses up to $70 \%$ have been documented in heavily infected crops [6]. 


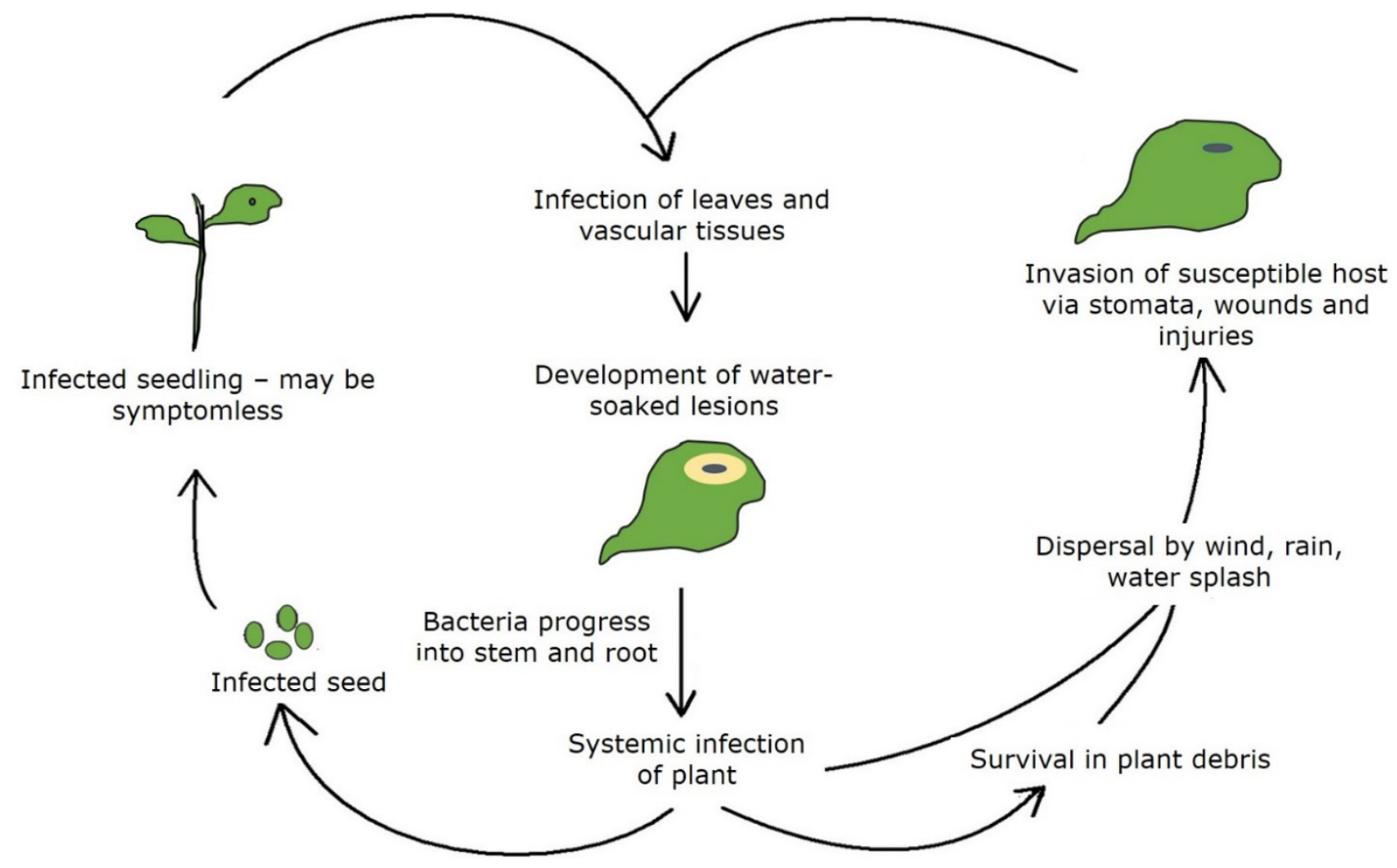

Figure 3. Schematic representation of the life cycle of Pseudomonas savastanoi pv. Phaseolicola, causing halo blight of mungbeans.

\section{Management of Halo Blight}

Management of halo blight is difficult as there are no registered chemicals for effective in-crop control of the disease. Tolerance level in the seed is low such that, when conditions are conducive, only one infected seed in 10,000 is sufficient to start an outbreak [7]. This prompted many countries to undertake highly sensitive and specific testing protocols to detect the presence of halo blight bacterium in seed crops [8]. Crops are rejected when the bacterium is detected or observed in or near seed production sites. Currently, the Australian Mungbean Association requires all seed crops to be tested, based on DNA detection method, for the presence of the halo blight bacterium in the seed. This represents a significant step towards producing certified, halo blight free seed. Comprehensive testing of seed crops for all the major bacterial diseases will identify potential disease problems, reducing the risk of pathogen spread. Diagnostic methods, such as those that employ DNA markers, appear to be more robust in detecting bacterial pathogens such as halo blight, even when there are no visible symptoms on the infected seeds $[8,9]$.

Improved resistance to halo blight has become available in the last five years through variety releases from National Mungbean Improvement. Opal-AU (released 2020) is a large green shiny-seeded mungbean in the same market class as Crystal and Jade-AU. Opal-AU is adapted to Southern Queensland and New South Wales and represents the biggest single step forward in disease resistance for mungbean. In the niche small green shiny-seeded market class, Celera II-AU (released 2015) has good protection from halo blight. More details on yield and agronomic performance, disease profiles and marketing of these are provided in the Variety Management Packages at http:/ /www.mungbean.org. au/agronomy.html (accessed on 17 May 2021).

Author Contributions: A.S.A. conceived the idea of the paper, revised the literature and drafted the manuscript. C.D. drafted the halo blight management section and provided comments on the article. All authors have read and agreed to the published version of the manuscript.

Funding: This research received no external funding other than what is specified in the acknowledgments. 
Institutional Review Board Statement: Not applicable.

Informed Consent Statement: Not applicable.

Data Availability Statement: Not applicable.

Acknowledgments: This paper has been developed as part of the National Mungbean Improvement Program (NMIP). The NMIP is a joint investment between the Department of Agriculture and Fisheries and Grains Research and Development Corporation aiming to improve productivity and reliability of the Australian mungbean industry.

Conflicts of Interest: The authors declare no conflict of interest.

\section{References}

1. Noble, T.J.; Young, A.J.; Kelly, L.A.; Barrerro, R.A.; Douglas, C.A.; Long, H.; Williams, B.; Mundree, S. Characterisation of the Pseudomonas savastanoi pv. phaseolicola population found in Eastern Australia associated with halo blight disease in Vigna radiata. Australas. Plant Pathol. 2020, 49, 515-524. [CrossRef]

2. Marques, A.S.d.A.; Samson, R. Population dynamics of Pseudomonas savastanoi pv. phaseolicola in bean, throughout the epiphytic and pathogenic phases. Pesqui. Agropecuária Bras. 2016, 51, 623-630. [CrossRef]

3. Noble, T.J.; Young, A.J.; Douglas, C.A.; Williams, B.; Mundree, S. Diagnosis and management of halo blight in Australian mungbeans: A review. Crop. Pasture Sci. 2019, 70, 195-203. [CrossRef]

4. Allen, S.; Kochman, J. Eliminating seed-borne inoculum of Fusarium oxysporum f. sp. vasinfectum in cotton. In Proceedings of the Beltwide Cotton Conference, Australian Cotton Cooperative Research Centre, Narrabri, Australia, 9-13 January 2001 ; pp. 139-140.

5. Bashan, Y. Mechanisms of symptom production by foliar bacterial pathogens. Phytoparasitica 1987, 15, 197-223. [CrossRef]

6. Ryley, M.; Douglas, C.; Ryan, M.; Tatnell, J.; Martin, W.; King, K.; Keller, L. Integrated management of foliar pathogens of mungbean in Australia. In Proceedings of the Australian Summer Grains Conference, Gold Coast, Queensland, Australia, 21 June 2010; pp. 1-9.

7. Taylor, J. The quantitative estimation of the infection of bean seed with Pseudomonas phaseolicola (Burkh.) Dowson. Ann. Appl. Biol. 1970, 66, 29-36. [CrossRef]

8. Rico, A.; Lopez, R.; Asensio, C.; Aizpun, M.T.; Asensio-S-Manzanera, M.C.; Murillo, J. Nontoxigenic strains of Pseudomonas syringae pv. phaseolicola are a main cause of halo blight of beans in Spain and escape current detection methods. Phytopathology 2003, 93, 1553-1559. [CrossRef] [PubMed]

9. Borowicz, B.; Maćkowiak, A.; Pospieszny, H. Improved identification of Pseudomonas savastanoi pv. phaseolicola at the molecular level. EPPO Bull. 2002, 32, 467-469. [CrossRef] 